\title{
Recent changes in the winter distribution and movements of northern Atlantic cod (Gadus morhua Linnaeus, 1758) on the Newfoundland-Labrador Shelf
}

\author{
David W. Kulka, J. S. Wroblewski, and \\ Savi Narayanan
}

Kulka, D. W., Wroblewski, J. S., and Narayanan, S. 1995. Recent changes in the winter distribution and movements of northern Atlantic cod (Gadus morhua Linnaeus, 1758) on the Newfoundland-Labrador Shelf. - ICES J. mar. Sci., 52: 889-902.

\begin{abstract}
Using catch data collected by fishery observers from the otter trawl fleet, we describe changes in the winter distribution of cod on the Newfoundland-Labrador Shelf between 1980 and 1992. We determined the relative abundance of cod in three areas of winter aggregation: south-east of Hamilton Bank, south-east of Belle Isle Bank and south-east of Funk Island Bank. The principal finding was that the cod, during their reproductive period, exhibited significant changes in distribution and behaviour, well before the stock showed signs of collapse. There were three indicators of these changes. First, there was a progressive disappearance of fish from the north with time. Most of the biomass was located in the Hamilton Bank area before 1984. By 1989, most of the fish were found at the Belle Isle Bank and south-east of Funk Island Bank locations and by 1991, only to the south (Funk Island Bank). Second, movements of the prespawning/spawning schools became more limited. Compared with the extensive along-shelf migrations, often covering distances of about $100 \mathrm{~km}$, observed in earlier years, the fish schools after 1989 exhibited less movement to the north. Density of fish in the schools was highest in 1990. By 1991, the schools remained nearly stationary around $49^{\circ} 30^{\prime} \mathrm{N}$, near the southern end of their distribution. Third, the schools spread over an increasingly greater range of depths. The greatest density of fish as reflected by high catch rates was generally observed no deeper than $600 \mathrm{~m}$ between 1980 and 1988 . By 1989-1990, substantial catch rates were observed as deep as $1100 \mathrm{~m}$, particularly to the north although catches continued to be considerable at the shallower depths. These changes in distribution and behaviour were generally coincident with the occurrence of anomalously cold ocean temperatures and heavy ice conditions, but no direct link between these changes and the environment was evident.
\end{abstract}

(C) 1995 International Council for the Exploration of the Sea

Key words: prespawning/spawning distribution, movements, northern Atlantic cod, fisheries observers, environmental changes.

Received 9 January 1995; accepted 4 August 1995.

D. W. Kulka*, J. S. Wroblewski† and S. Narayanan*: *Department of Fisheries \& Oceans, Northwest Atlantic Fisheries Centre, Box 5667, St John's, Newfoundland, Canada AIC $5 X 1$ and $†$ Fisheries Oceanography Group, Ocean Science Centre, Memorial University of Newfoundland, St John's, Newfoundland, Canada A1B $3 X 7$.

\section{Introduction}

Northern Atlantic cod (Gadus morhua) on the north-east Newfoundland and Labrador Shelves (NAFO Divisions $2 \mathrm{~J}, 3 \mathrm{~K}$ and $3 \mathrm{~L}$ ) was the most important groundfish resource off Canada's Atlantic coast for more than 400 years (Lear and Parsons, 1993). It continued to be the primary resource for both the inshore and offshore fishing sectors into the 1980s. From 1980 until 1990, assessments indicated that stock size had fluctuated without trend (Baird et al., 1992), suggesting a stable population during this period. Bishop et al. (1993) noted that the decline in population size first became evident from the fall 1990 research survey and, from then on, the biomass fell rapidly and apparently with little warning. The fishery with a peak catch of $268677 \mathrm{t}$ in 1988 was closed in 1992. In annual assessments of this stock based primarily on biomass estimates from fall surveys and commercial catch data, no early signals that might be associated with change in the population were reported.

Hilborn and Walters (1992) stated that a fundamental component of fisheries population models and manage- 
ment programs is the distribution of the stock in space and time. Having some knowledge of the distribution and movement of the fish during their reproductive period is particularly important as this provides important clues to stock structure. Harris (1990) noted the paucity of such information for this and other Atlantic stocks. Reviews of northern cod biology by Lear (1986), deYoung and Rose (1993) and Taggart et al. (1994) show that much of the field research on Labrador and north-east Newfoundland Shelf cod had occurred during the summer or fall period. For example, Bishop et al. (1993) and Lilly (1994) described the distribution of cod, the latter with respect to their prey, but these studies took place in the fall prior to reproduction. Lear (1984, 1986), Lear and Green (1984) and Rose (1993), using tagging and acoustics, described migratory activity of northern cod during the fall and spring. For the inshore areas, landings data yielded only limited information on the summer distribution (Davis, 1991; Lear and Parsons, 1993). Winter hydroacoustic surveys have been conducted offshore since 1986 but the data collected prior to 1991 were not usable (Bishop et al., 1993). Except for (Wroblewski et al., 1995), there is little information on the spawning distribution of northern cod, particularly during the period leading up to the decline. Thus, past studies on the Labrador/ Newfoundland Shelf component of adult cod have, for the most part, covered the inshore and migratory phases leaving a gap in our knowledge of the spawning distribution.

Understanding the distribution and movements of adult cod during reproduction is important because spatial dynamics of spawning activity relative to stock range can affect reproductive success (deYoung and Rose, 1993). Through a reappraisal of past and recent work, they postulated that a southerly shift in the distribution of northern cod had occurred commencing in 1988. However, their analyses were based mainly on data from fall surveys that occur prior to the reproductive period of cod. The only data available for the winter, were catch and fishing effort from the otter trawl fishery, gathered by observers. Geo-referenced set records, for the period January to April, encompassed the peak of spawning for the north-east Newfoundland and Labrador Shelf as described by Myers et al. (1993), and the majority of cod captured during this fishery were of reproductive age, primarily $4+\mathrm{yr}$ (Bishop et al., 1993). Qualitative data collected by the observers during the fishery showed that the fish in these schools were maturing or in spawning condition (Wroblewski et al., 1995). We used this information to study the adult component of the population during their reproductive period.

A preliminary analysis of these data by Rose et al. (1994) looked at average biomass as a function of latitude and depth. Their study indicated shifts of the cod to the south and into deeper waters, and this prompted us to examine these changes in distribution in more detail. In the present paper we describe the spatial structure and behaviour of the schools of adults prior to and during the sudden downturn in biomass. Specifically, over the period 1980-1992, we examine the relative amounts of biomass at three locations where the prespawning and spawning cod tended to aggregate. We look at distributional shifts by depth and investigate along-shelf movements of schools at a weekly time scale just prior to and during the biomass decline of 1989 1992. These patterns are compared with the patterns described by Wroblewski et al. (1995) for 1986-1988, when behaviour of schools was more typical of earlier years.

\section{Methods}

Observers stationed on board a portion of the trawler fleets of all countries fishing for groundfish during January to April, 1980-1992 collected details of the fishing operation by standard methods outlined in Kulka and Firth (1987). The data were collected from depths of $40-1400 \mathrm{~m}$ and covered much of the shelf in NAFO Divs 2J, 3K and $3 \mathrm{~L}$ (Fig. 1) for each year of the study. Catch and associated effort from a total of 55617 sets that contained cod $(55 \%$ of all otter trawl sets observed) were used to examine changes in the distribution and movement of cod.

The underlying assumption in using these data for distributional studies is that the extent of the commercial activity at that time of year encompasses the main body of fish. The similar but more dispersed distribution from fall surveys (Bishop et al., 1993; Lilly, 1994), compared with the concentrated, shelf-edge distribution observed in this study, suggests that the fishing grounds do indeed encompass the stock. Areas of low cod concentration were also sampled. Considerable fishing activity with negligible or no cod catches, from areas adjacent (both landward and seaward) to where large catches were taken, further supports the view that concentrations in surrounding areas were not missed, with the possible exception of the extreme north-west of the study area. Heavy ice may have restricted activity there in some years. Fall research vessel surveys show significant amounts of cod at that location (Bishop et al., 1993; Lilly, 1994). However, limited fishing in that area in the winter yielded only low catch rates.

Catch rate, expressed in $\mathrm{kg} \mathrm{h}^{-1}$, was standardized using the multiplicative model (Gavaris, 1980) to correct for variation in vessel tonnage class (related to fishing power) and country. Factors previously recognized as affecting the interpretation of CPUE data are tonnage category, country, area, season, and gear. Area, season, and gear were not confounding factors for this analysis because our spatial analysis more appropriately 


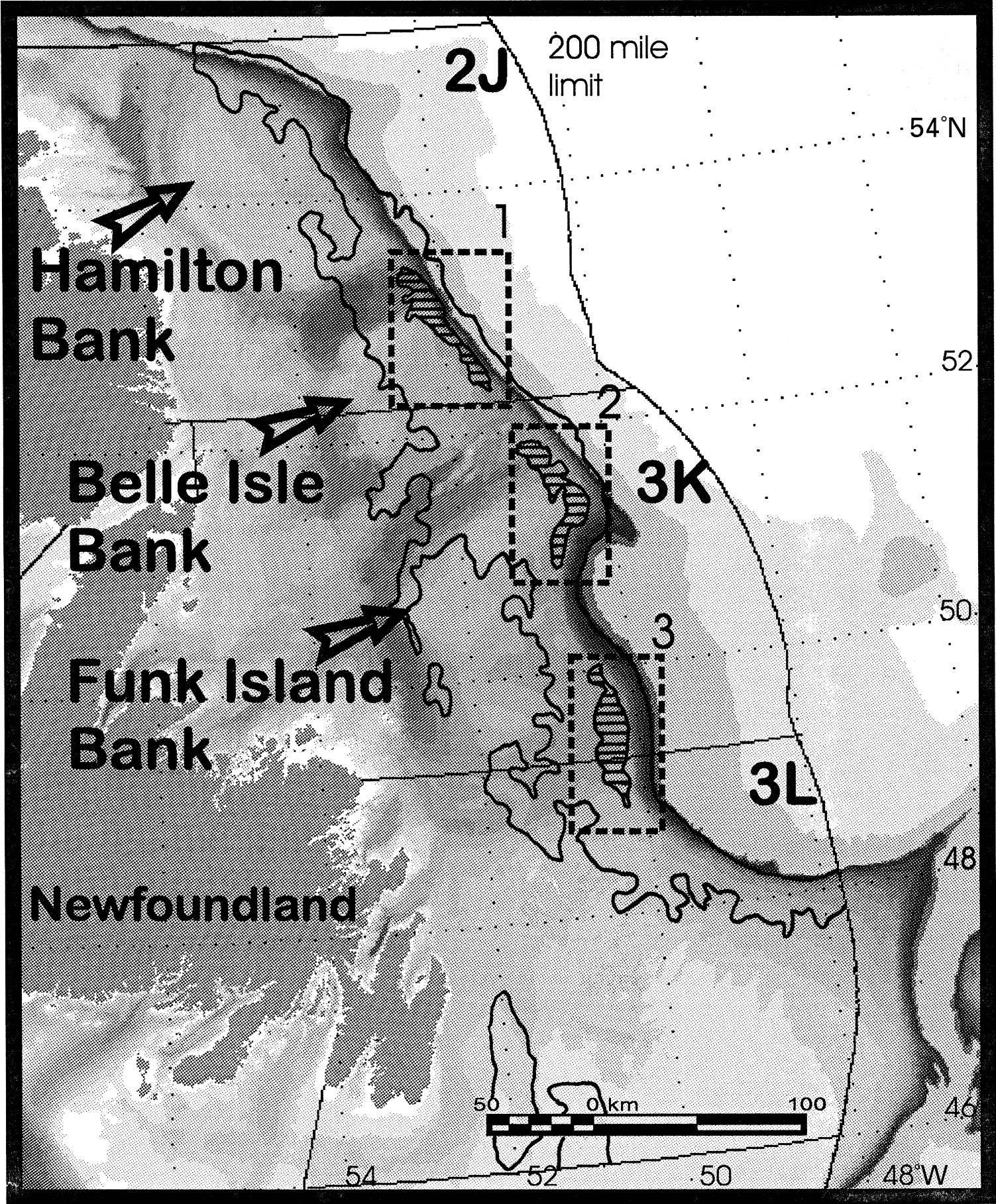

Figure 1. Winter distribution of northern Atlantic cod (January to April) averaged over 1980-1991 (modified from Wroblewski et al., 1995). The irregular outline of an area stretching from just south of $48^{\circ} \mathrm{N}$ to $55^{\circ} \mathrm{N}$ plus two areas on the Grand Banks represents the extent of the observed cod concentrations (where catch rates exceeded $1.5 \mathrm{t} \mathrm{h}^{-1}$ ). The hatched areas within the boxes illustrates where the cod tended to congregate during the period of study and the boxes were used to examine shifts in the biomass. A Lambert Conformal projection was used. 
accounts for variation across areas. Our study covers only one season and only otter trawl data were used. On the other hand, vessels engaged in the fishery fall into five of the tonnage classes (TC) based on gross registered tonnage (GRT): TC 3 (50-149.9), 4 (150-499.9), 5 (500 999.9), 6 (1000-1999.9) and 7 (2000 GRT and over). Canadian vessels were in classes 3 to 6 although class 5 vessels dominated the fishery. Other countries employed class 7 vessels.

While the possibility of variation in catchability, due to such factors as gear-related changes during the 1980s, is recognized by the authors, it is not likely to have had a significant effect on this distributional analysis because any changes would be likely to be similar over the entire study area. In addition, a number of factors remained constant throughout the study period. The same extensive area was fished (or explored) between years; overall, the same vessels dominated the fishery throughout the period of study and consistent fishing strategies were used by the fleet over the years. Ease of locating and staying with fish concentrations in any year and consistent fleet strategies suggested no significant change in fishing habits and thus catchability during our period of study.

Set data consisting of latitude, longitude, and catch rate (converted to TC 5 standard) were imported into SPANS (Intera Tydac ${ }^{(\mathrm{I})}$ ). The basic format for output in SPANS is a refinement of a raster format called quadtree structure (Burrough, 1986) which uses a variable sized pixel or "quadcell". These quadcells form a grid over the study area and provide the locations to which estimates calculated by a scanning circle, described below, are assigned. The size of the quadcell used in the present analysis was $0.04 \mathrm{~km}^{2}$ because it provided smoother graphical output (maps of density subareas). However, quadcell size of up to the equivalent of the scanning circle used by potential mapping as described below provides equivalent biomass estimate results.

The point data (fishing sets with the attribute catch rate adjusted from tonnes $\mathrm{h}^{-1}$ to tonnes per area swept by the trawl) were converted to continuous density surfaces by the potential mapping technique. Once potential mapping sets up a grid of quadcells, a circle of specified diameter moves from one grid location to the next calculating an average catch $\mathrm{h}^{-1}$ for all points that fall within the circle. For this study, size of the scanning circle was set to a diameter of $14 \mathrm{~km}$, the average length of a fishing set. This insured that smoothing of the data resulting from averaging of points within the circle was on the same scale as the fishing set. In addition, this dimension is on the scale of cod schools as reported by Rose (1993). The procedure is performed for every quadcell within the study area and an integration of classified quadcells forms a density surface.
The mean catch rate over quadcells would represent mean density over the entire area fished, and density multiplied by area fished gives an estimate of biomass. However, the SPANS software requires that the thousands of different quadcell values created by potential mapping be classified. The number of classification levels is set by the user. Additionally, the method stratifies density and thus accounts for differences over area in deriving an estimate of biomass. The quadcell values were grouped into 12 classes and these were used for parameter estimation as follows:

class 1: 0 cpue to account for observations (quadcells) with zero catch rates

classes 2-11: equal intervals of 1.5 tonnes $\mathrm{h}^{-1}$

class 12 : cpue $>15$ tonnes $\mathrm{h}^{-1}$.

Classification into 12 classes assured that the estimate of class density was not biased. Below a certain threshold, the number of density classes into which the quadcell values are categorized affects the index of biomass. The biomass estimate decreases asymptotically as the number of classes is increased. This is because catch rate data are skewed. SPANS uses the midpoint of the class (not class mean) and, with very few classes, the midpoint of the class is considerably larger than the mean of the data in that class. As the number of classes increases, midpoint and mean merge. Beyond 10, the class midpoint and the mean are almost identical. Based on this, the number of classes chosen for the analysis of cod was 12 , including class 1 to account for zero values and class 12 to account for the few very large catch rates (>15 tonnes $\left.\mathrm{h}^{-1}\right)$.

Using areal expansion, density when modelled with area yields an estimate of biomass using the formula from Kulka (1990):

$\mathrm{B}={ }^{\mathrm{n}} \sum\{(\mathrm{a} \times \mathrm{c}) /[(\mathrm{t} \times \mathrm{w}) / \mathrm{h}]\}$

where $\mathrm{B}=$ biomass

$\mathrm{n}=$ number of catch rate classes

$\mathrm{a}=$ area of catch rate class

$\mathrm{c}=$ midpoint of catch rate class $\left(\mathrm{kg} \mathrm{h}^{-1}\right)$

$\mathrm{t}=$ average tow length

$\mathrm{w}=$ wingspread of net $(\mathrm{km})$

$\mathrm{h}=$ average number of hours per tow

Although towing speed was recorded on a set-by-set basis and nominal wingspread was available for each net type used, estimates of the latter generally did not vary for the particular gear and varied little among vessels. Thus, wingspread was taken as a constant $0.02 \mathrm{~km}$, this being the most consistent value reported by captains during the study period. It was noted, however, that the average towing speed declined over time, with a maximum of $7.2 \mathrm{~km} \mathrm{~h}^{-1}$ in 1980 and a minimum of $5.6 \mathrm{~km} \mathrm{~h}^{-1}$ in 1991. Thus, average tow length was calculated for each year. 


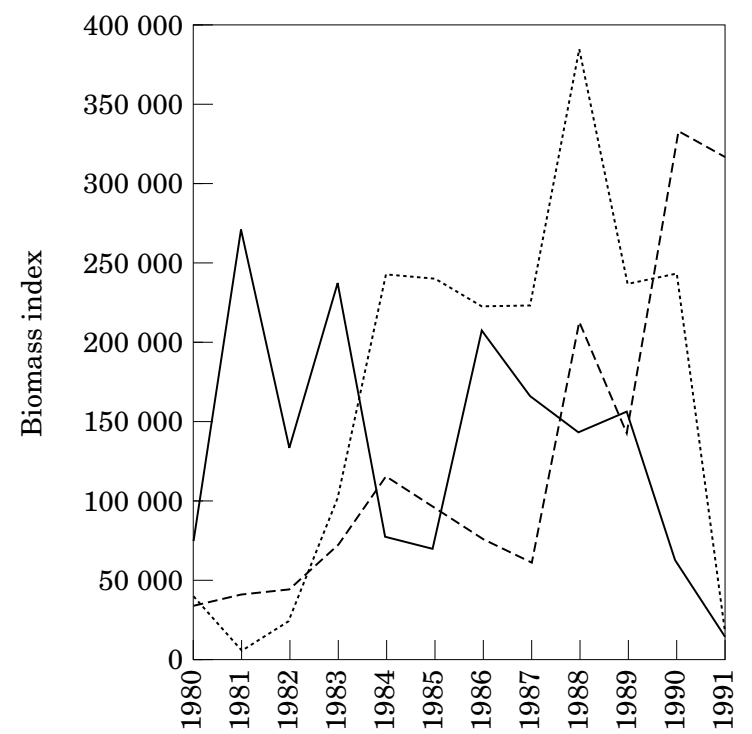

Figure 2. Annual trends in biomass from 1980-1991 as calculated for each of the three boxes illustrated in Figure 1. $(-)$ North (1); ( ․) middle (2); (-- ) south (3).

A density contour map constructed in the manner described above was produced for each year. Wroblewski et al. (1995) identified three locations (Fig. 1) along the shelf edge where the fish tended to congregate; in the northern, middle, and southern part of the winter distribution. Based on the observed pattern, boxes of approximately equal size covering a total of $16 \%$ of the area fished and where $70 \%$ of the biomass was located, were used to delineate the three areas of persistent aggregation of cod. NAFO Divisions were not used for examining shifts in biomass as they do not reflect how the cod were distributed. As an example, the dividing line between NAFO Divisions $3 \mathrm{~K}$ and $3 \mathrm{~L}$ passed through the centre of the southern most concentration and two locations of aggregation fell within NAFO Division 3K.

Biomass was calculated using Equation (1) within each box for each year between 1980 and 1991. Due to termination of the fishery in late February, it was not possible to carry out the analysis for 1992. Annual biomass within these boxes was plotted for each location to show the temporal trends relative to the three areas where the cod tended to concentrate (Fig. 2).

Location of the fish with respect to depth was examined by plotting average catch rate expressed in $\mathrm{t} \mathrm{h}^{-1}$ against depth. Data from sets in each of the three boxes illustrated in Figure 1 were averaged over four periods, 1980-1982, 1983-1985, 1986-1988, and 1989-1991. Each group consisted of years of more or less analogous environmental conditions: the warmer years of the early 1980s and late 1980s, and the colder years of the mid-1980s and the 1990s (Rose et al., 1994). The result- ing plots of catch rate at depth over time were used to illustrate changes in fish density with respect to depth over time relative to the three areas where the cod tended to concentrate. The significance of the differences in mean catch rates as shown in Figure 3 was tested with analysis of variance and multiple comparison of means using the method of Scheffe (1959). For each box separately, catch rates expressed as $\mathrm{kg} \mathrm{h}^{-1}$ were first $\log$-transformed to normalize their distribution (see Gulland, 1956) and averages of log-transformed catch rates for each year group, 1980-1982, 1983-1985, 1986-1988, and 1989-1991 were compared within each $100 \mathrm{~m}$ depth range. Pairwise comparisons were performed for each year group within each depth range.

Along-shelf movements of schools of cod at a weekly time scale were examined for the months of January to April during 1989-1991, and January to February 1992, after which a moratorium was declared. Each month contained between 534 and 1739 trawler positions (Table 1, Fig. 4) where cod were caught either in the directed fishery or as bycatch with other species (except February 1992 when the fishery was terminated and where only 199 sets were obtained). Table 1 specifies the total number of observed fishing sets by year. Table 2 shows the number of these tows with catch rates exceeding $5000 \mathrm{~kg} \mathrm{~h}^{-1}$.

Assuming that clusters of high density tows $(5000 \mathrm{~kg}$ $\mathrm{h}^{-1}$ was selected as the lower limit) indicated dense schools of cod, these large catches were plotted on a weekly basis. Our analyses of the movements of cod schools are based on the assumptions that the collective position of trawlers making high catch rates reflected positions of fish aggregation, and that fishing effort generally encompassed these concentrations of fish. The presence of fishing sets with low or no cod catches surrounding the shifting aggregations of large catches suggests that we were observing moving schools. Thus, assemblages of high density tows that remained cohesive over several weeks were considered to be indicative of the movements of concentrations of cod.

\section{Results}

For 1980-1991, Figure 1 shows that, during the winter, dense concentrations of cod were found in a $400 \mathrm{~km}$ band (delineated by the irregular outline) along the shelf edge north of $47^{\circ} 00^{\prime} \mathrm{N}$. Cod schools were most persistently found in the hatched areas located to the east or south-east of deep trenches leading shoreward. Based on this distribution, biomass calculated within three boxes positioned where the schools were most consistently found is shown in Figure 2. Annual trends in the biomass in each box reflected distributional shifts given that, on average, a majority of the biomass of cod $(70 \%)$ was situated in the three boxes that covered only $16 \%$ of the study area. 

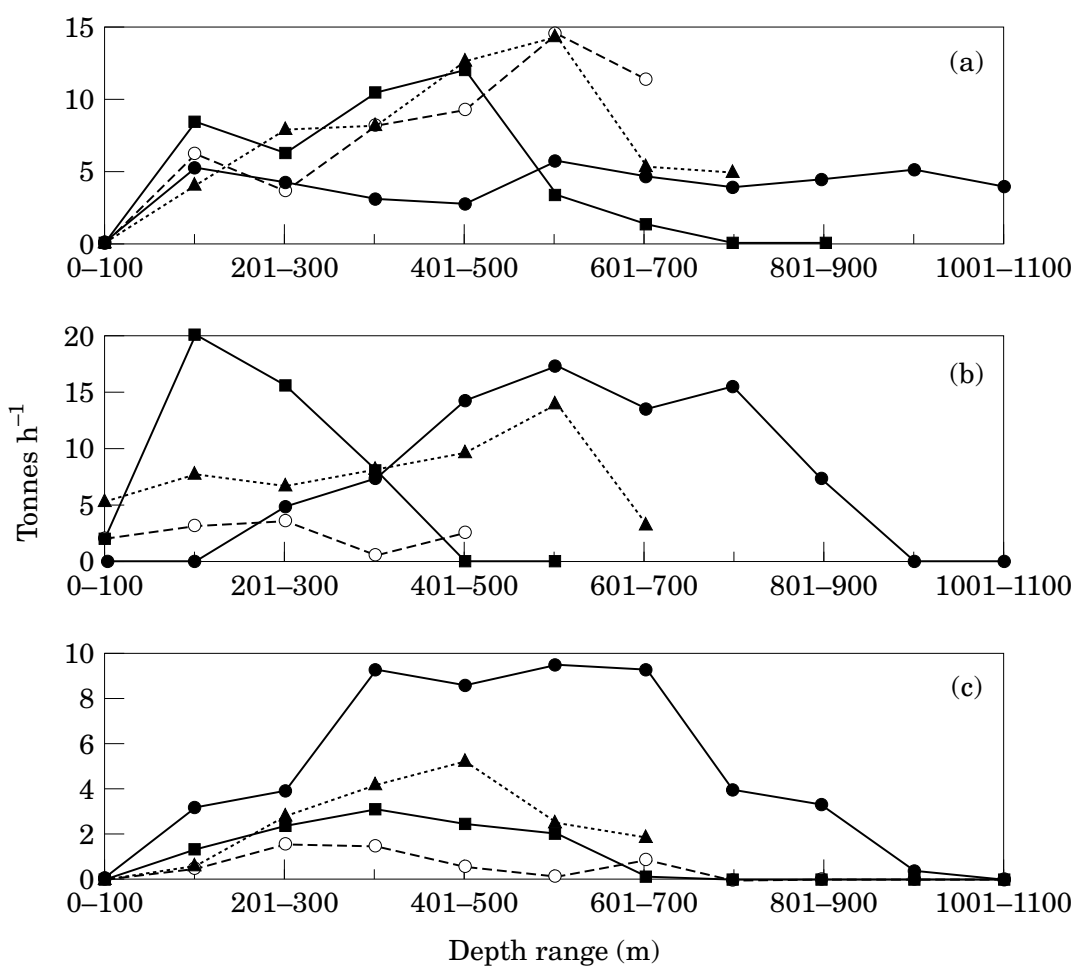

Figure 3. Catch rate by $100 \mathrm{~m}$ depth intervals within each of the three boxes illustrated in Figure 1: (a) northern box, (b) middle box and (c) southern box. $\bullet=1989-1991 ; \boldsymbol{\Lambda}=1986-1988 ; \boldsymbol{\square}=1983-1985 ; \bigcirc=1980-1982$.

Table 1. Number of Newfoundland Fisheries Observer Program records in January to April, 1989-1992.

\begin{tabular}{lcccc}
\hline \multicolumn{5}{c}{ Month } \\
\cline { 2 - 5 } Year & January & February & March & April \\
\hline 1989 & 1593 & $604^{*}$ & $1327^{*}$ & 1739 \\
1990 & 1200 & 1095 & 534 & 1209 \\
1991 & 1028 & 686 & 578 & 573 \\
1992 & 998 & $199^{* *}$ & - & - \\
\hline
\end{tabular}

*No fishing occurred in NAFO divisions $2 \mathrm{~J}$ and $3 \mathrm{~K}$ from February to late March 1989 due to a strike in the industry.

**The Canadian domestic offshore fishery for northern cod was closed in late February 1992.

Between 1980 and 1983, the majority of biomass, $50-85 \%$, was found in the most northerly box (1) that was located between $52^{\circ} 16^{\prime} \mathrm{N}$ and $53^{\circ} 28^{\prime} \mathrm{N}$, completely within NAFO Div. 2J. During the cold years of 1984 and 1985, the biomass at this location dropped then recovered (shifted north again) in 1986, a warmer year. From 1986-1988, biomass declined gradually then dropped rapidly to near zero after 1989 .

The middle box (2) bounded by $50^{\circ} 35^{\prime} \mathrm{N}$ and $51^{\circ} 59^{\prime} \mathrm{N}$ is located in the northern portion of NAFO Div. 3K. The biomass in this box was very low $(5-27 \%$ of the total) from 1980 until 1982, rose rapidly during 1983 and 1984 then levelled off until 1987. Its biomass then peaked in 1988. Furthermore, between 1984 and 1989, it contained the greatest proportion of the biomass of the three areas. After 1988, the biomass in the middle box declined even more dramatically than in the northern box, again to a value near zero.

In contrast, the biomass in the southern box (3) located between $48^{\circ} 46^{\prime} \mathrm{N}$ and $49^{\circ} 56^{\prime} \mathrm{N}$, straddling NAFO Div. 3K and 3L, rose steadily to 1984 , declined marginally up to 1987 then rose again rapidly. By 1990 , it contained $50 \%$ of the total biomass in the three boxes and in 1991, it contained 95\%. Thus, Figure 2 shows that the greatest proportion of the biomass was to the north off Hamilton Bank in NAFO Div. 2J until 1983 then shifted to the mid part of the distribution off Belle Isle Bank (northern NAFO Div. 3K) until 1989. By 1990, most of the biomass was concentrated to the east of Funk Island Bank at the border of NAFO Div. 3K and 3L. The years of greatest change were 1983-1984 and 1990-1991.

Patterns of catch rate expressed in tonnes $\mathrm{h}^{-1}$ and averaged by $100 \mathrm{~m}$ depth intervals over time (19801991) were complex (Fig. 3). Distribution by depth changed such that dense concentrations, as reflected by high catch rates, were spread over a greater range of depths with time, and particularly after 1989. However, 


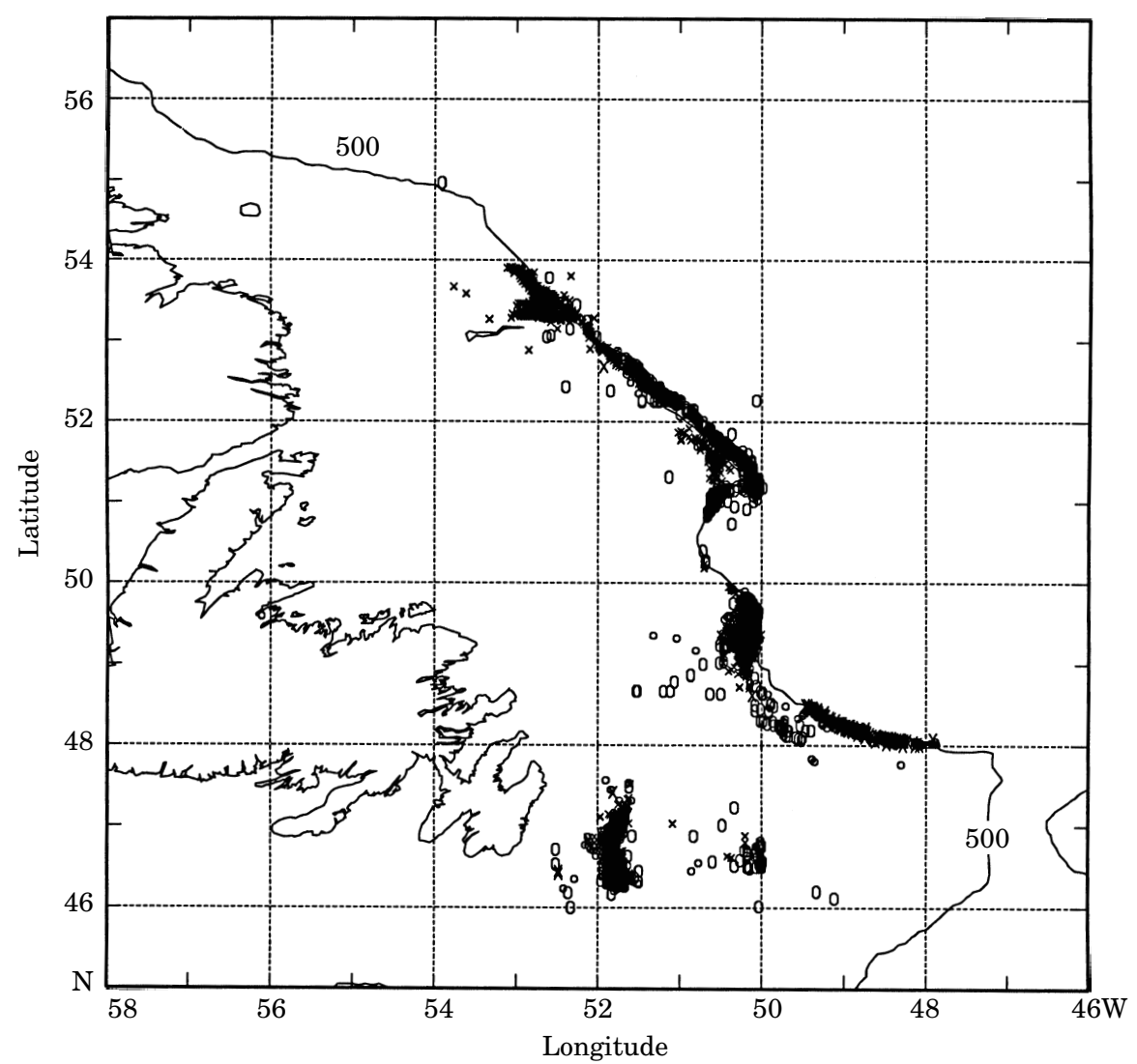

Figure 4. Plot of Newfoundland Fisheries Observer Program data for January-April 1989, showing all 5263 positions of otter trawl tows that caught northern cod during that period. Different symbols are used for each month: x, January; X, February; o, March; $\mathrm{O}$, April. Figures 4-8 have no geographic projection. The $500 \mathrm{~m}$ isobath is shown.

this pattern also varied with latitude. Catch rates in the northern box in 1980-1988 peaked between $400 \mathrm{~m}$ and $600 \mathrm{~m}$. After 1989, density was relatively low but consistent over a much wider range of depths between 100 and $1000 \mathrm{~m}$. For the middle box, density was low at all depths before 1982, peaked at $200 \mathrm{~m}$ for $1983-1985$ and at $400-600 \mathrm{~m}$ for $1986-1988$. After 1988 , the pattern was more protracted, peaking between 400 and $800 \mathrm{~m}$. Similarly in the southern box, density peaked at $300-500 \mathrm{~m}$ until 1988. High values were observed in 1989-1991 from about $300-700 \mathrm{~m}$. Except in the north (at 601$800 \mathrm{~m}$ ), substantial catch rates of cod were observed at depths greater than $600 \mathrm{~m}$ only after 1988. Although there was little fishing activity in the deeper waters for the years prior to 1988 , whenever fishing activity was observed at depths greater than $600 \mathrm{~m}$, catch rates there were consistently near zero suggesting no dense schools of fish at those depths in those years. Mostly low or nil cod catches from deep water fisheries to the east suggested no significant concentrations at depths exceeding $1000 \mathrm{~m}$ in any year before 1989.
An analysis of variance comparing means of logtransformed catch $\mathrm{h}^{-1}$ among year groups 1980-1982, 1983-1985, 1986-1988, and 1989-1991 within each $100 \mathrm{~m}$ depth range showed that the values were significantly different $(\alpha=0.05)$ for six of eight depth ranges in the northern box, six of six in the middle box, and nine of nine in the southern box. Using the method of Scheffe (1959) for multiple comparison, 78 of 117 pair-wise comparisons $(67 \%)$ of year group means within depth ranges were significantly different $(\alpha=0.05)$ confirming the patterns of year group points seen in Figure 3 .

Short (weekly) time scale analysis of trawler positions revealed a change in the behaviour of cod during the period of declining and southward shifting biomass (1989-1992), compared with patterns in earlier years (1986-1988). The cod schools became denser, fewer in number, and less migratory. In January 1989, trawlers located two major concentrations of cod, one near the south-east edge of Hamilton Bank centred at $53^{\circ} 30^{\prime} \mathrm{N}$ and another east of Funk Island Bank at $49^{\circ} 30^{\prime} \mathrm{N}$ (Fig. 5a). The northern school moved along the $500 \mathrm{~m}$ 
Table 2. Number of tow positions with catch rates $\geq 5000 \mathrm{~kg} \mathrm{~h}^{-1}$. In parentheses is the number of positions after grouping tows within a radius of $0 \cdot 1^{\circ}$ latitude and longitude.

\begin{tabular}{|c|c|c|c|c|c|}
\hline \multirow[b]{2}{*}{ Year } & \multirow[b]{2}{*}{ Month } & \multicolumn{4}{|c|}{ Week } \\
\hline & & 1 & 2 & 3 & 4 \\
\hline \multirow[t]{4}{*}{1989} & January & $65(18)$ & 207 (26) & $226(21)$ & $164(15)$ \\
\hline & February* & $118(11)$ & 145 (12) & 63 (12) & 86 (6) \\
\hline & March* & 83 (9) & 84 (6) & 33 (5) & 188 (18) \\
\hline & April & $182(22)$ & 154 (18) & $201(10)$ & $221(11)$ \\
\hline \multirow[t]{4}{*}{1990} & January & 66 (7) & 146 (12) & $234(15)$ & $248(16)$ \\
\hline & February & $179(10)$ & $201(12)$ & $216(10)$ & $167(12)$ \\
\hline & March & $82(11)$ & $61(9)$ & $26 \quad(5)$ & $91 \quad(5)$ \\
\hline & April & 117 (8) & $84(15)$ & 29 (7) & $28 \quad(8)$ \\
\hline \multirow[t]{4}{*}{1991} & January & 74 (9) & $220(12)$ & $136(11)$ & $189 \quad(7)$ \\
\hline & February & 121 & $124 \quad(5)$ & $114 \quad(7)$ & $103 \quad(6)$ \\
\hline & March & $95 \quad$ (9) & 68 (6) & $44 \quad$ (4) & $83 \quad$ (4) \\
\hline & April & $49 \quad(5)$ & $44 \quad(5)$ & $50 \quad(6)$ & $28 \quad(7)$ \\
\hline \multirow[t]{2}{*}{1992} & January & $92 \quad(5)$ & $65 \quad(7)$ & $71(11)$ & $115(12)$ \\
\hline & February** & $55 \quad(5)$ & $20 \quad(2)$ & $20 \quad(3)$ & $7 \quad(2)$ \\
\hline
\end{tabular}

*No fishing occurred in NAFO divisions 2J and 3K from February to late March 1989 due to a strike in the industry.

**The Canadian domestic offshore fishery for northern cod was closed in late February 1992.

contour toward lower latitudes, travelling distances of up to $75 \mathrm{~km}$ in January. Since there was no fishing in NAFO Divs $2 \mathrm{~J}$ and $3 \mathrm{~K}$ from February to late March due to a strike in the industry, the along-shelf movements of the northern aggregation during this period are unknown. However, in April, the most northerly school may have moved south to $51^{\circ} \mathrm{N}$ (Fig. 5b). The southern concentration of cod apparently remained relatively stationary, moving between $49^{\circ} \mathrm{N}$ and $50^{\circ} \mathrm{N}$ from the start of January to late April (Figs 5a,b).

A different distribution of the schools is apparent for 1990. January was unusual in that cod east of Funk Island Bank at $51^{\circ} 00^{\prime} \mathrm{N}$ constituted the most northerly school observed (Fig. 6a). Ice conditions in January did not prevent trawlers from fishing further north and scouting trips in that area did not find commercial concentrations of cod. Catches at a rate $>5000 \mathrm{~kg} \mathrm{~h}^{-1}$ were not observed in NAFO Div. 2J until the fourth week of March at $52^{\circ} 30^{\prime} \mathrm{N}$ (Fig. 6b). That concentration remained at the same location until the second week of April. In addition, a school of cod located at $49^{\circ} 30^{\prime} \mathrm{N}$ remained nearly stationary from the first week of January 1990 (Fig. 6a) until the third week of April (Fig. 6b).

In 1991 and 1992 (until closure of the fishery in late February, 1992), no catches exceeding $5000 \mathrm{~kg} \mathrm{~h}^{-1}$ were taken north of $50^{\circ} 30^{\prime} \mathrm{N}$ (Figs 7,8) except for a few scattered sets at $51^{\circ} 00^{\prime} \mathrm{N}$ in January 1992. As in 1989 and 1990, ice did not prevent trawlers from searching the northern area for schools of cod and this they did. Exploratory fishing along the $500 \mathrm{~m}$ isobath in NAFO Div. 2J during the third and fourth weeks of March 1991 located no commercial concentrations of cod. Catch rates there were mostly $<20 \mathrm{~kg} \mathrm{~h}^{-1}$, with only six sets between 200 and $750 \mathrm{~kg} \mathrm{~h}^{-1}$. In early January 1991, the only significant concentration of cod was found along the $500 \mathrm{~m}$ isobath at $50^{\circ} 10^{\prime} \mathrm{N}$, near the boundary of NAFO Divs 3K and 3L (Fig. 7). This same concentration was fished during February, March, and April (Fig. 7) at about the same location. In 1992, the major concentation of cod was observed on the northern edge of the Grand Bank along the $500 \mathrm{~m}$ isobath (Fig. 8).

The density of cod (as indicated by catch rates) in the schools (defined as clusters of tows where catch rates exceeded $5000 \mathrm{~kg} \mathrm{~h}^{-1}$ ) increased significantly during 1990 , and then returned to levels seen in previous years (1986-1988, Fig. 9) although extent of the distribution was diminished. Fish densities in schools during January and February 1992 were similar to those observed in 1991.

\section{Discussion}

Bishop et al. (1993) showed that, for the fall period, after 1988, a portion of the biomass in NAFO Div. 2J disappeared rapidly while increasing in NAFO Divs $3 \mathrm{~K}$ and $3 \mathrm{~L}$. In the present study we show the change in distribution that started about five years before the decline in biomass, corroborating the latitudinal shifts described by Rose et al. (1994). A biomass shift, although not consistently north to south, started in about 1984 and also, after 1990, the schools occupied a greater range of depths. Furthermore, the extensive bi-directional shelf-edge movements of schools observed during 1986-1988 (Wroblewski et al., 1995) started to change in 1989. In that year, the cod schools were 

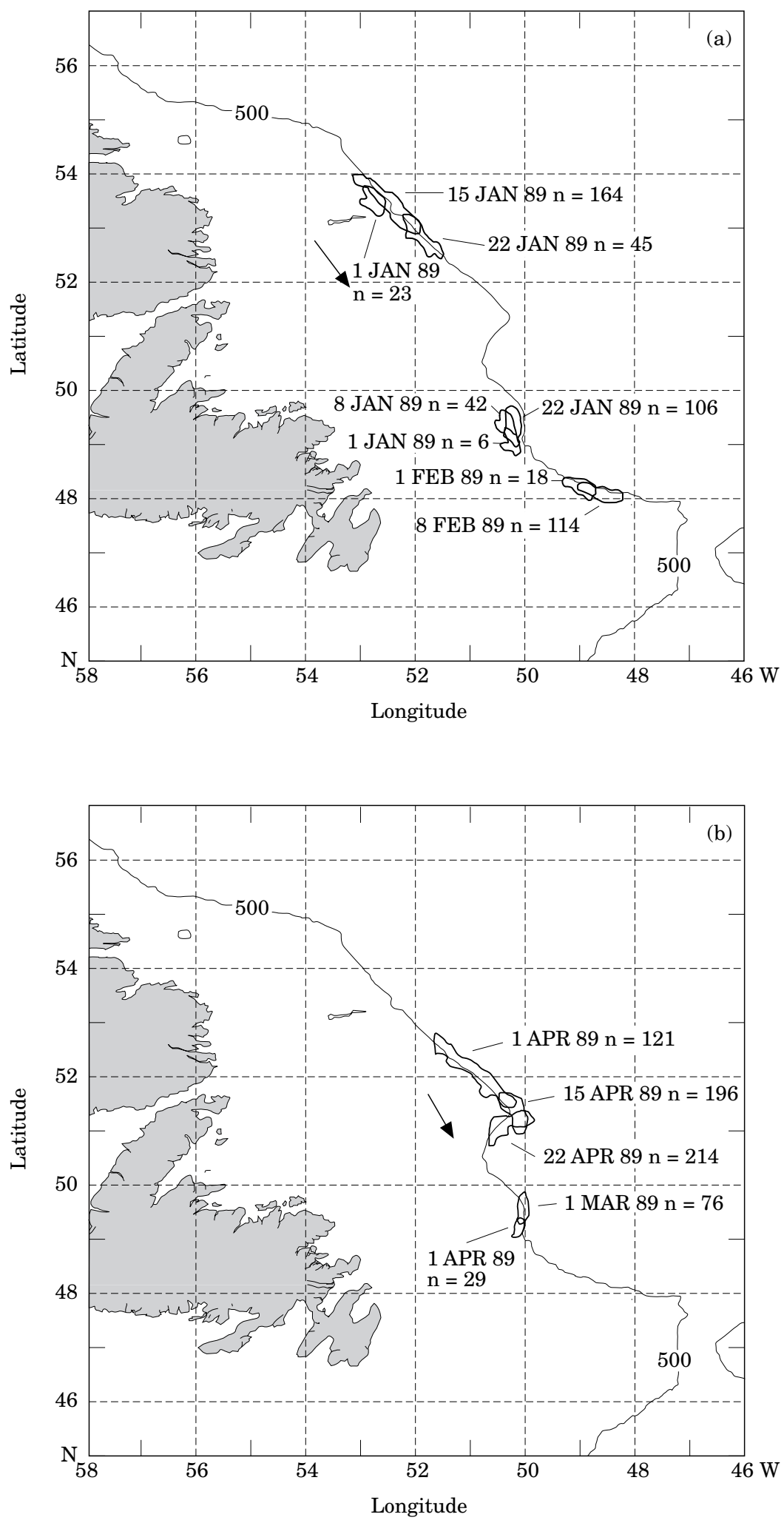

Figure 5. Clusters of tows catching $>5000 \mathrm{~kg} \mathrm{~h}^{-1}$ of cod during (a) January and early February 1989 and (b) April 1989. The value of $\mathrm{n}$ is the number of tows in the cluster. 

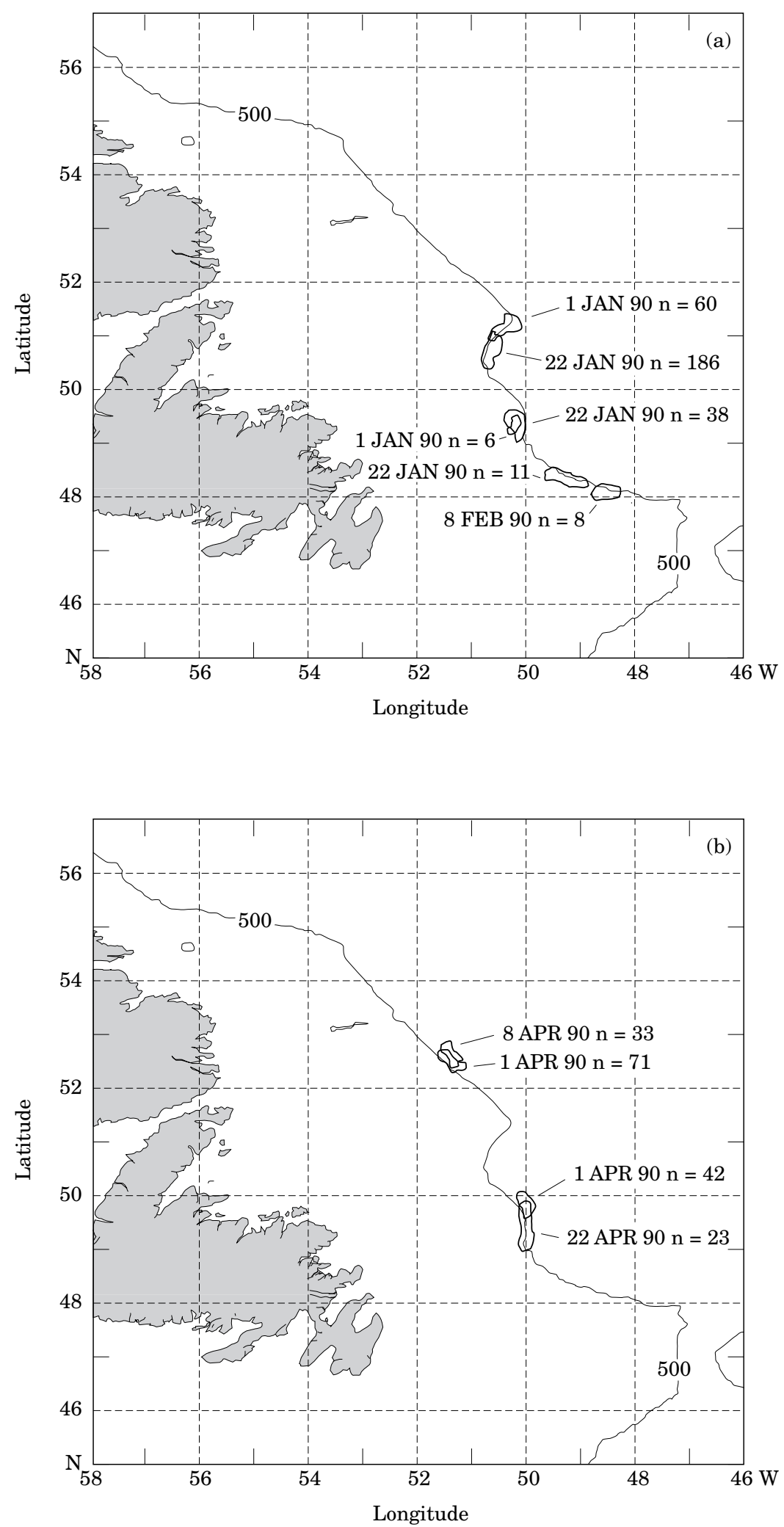

Figure 6. Clusters of tows catching $>5000 \mathrm{~kg} \mathrm{~h}^{-1}$ of cod during (a) January and early February 1990 and (b) April 1990. 


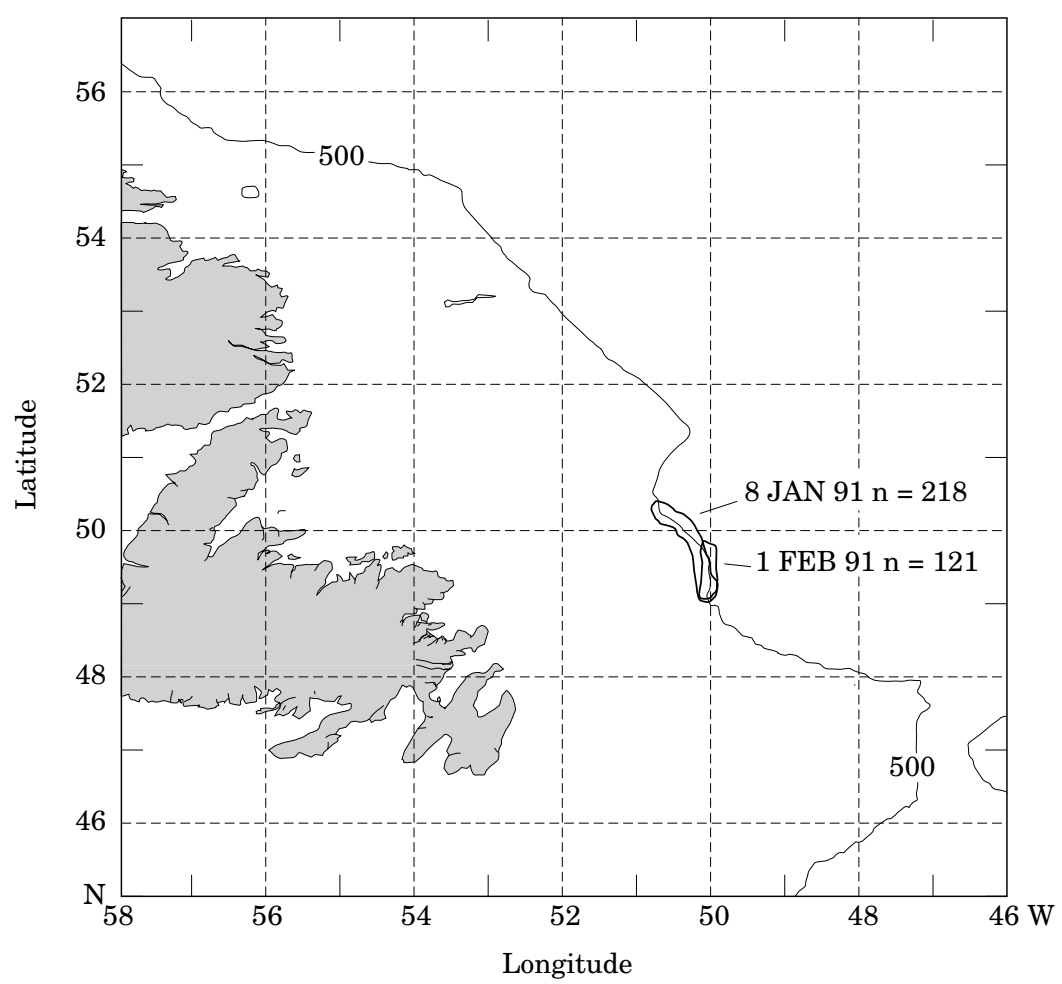

Figure 7. Clusters of tows catching $>5000 \mathrm{~kg} \mathrm{~h}^{-1}$ of cod during January and early February 1991.

observed to move primarily southward. In conjuction with the period of rapidly declining biomass, the movements were greatly diminished in 1990 and undetectable in 1991-1992. Cod schools remained at the southern extent of the distribution at the border of NAFO Divs $3 \mathrm{~K}$ and $3 \mathrm{~L}$ or moved eastward along the $500 \mathrm{~m}$ isobath onto the edge of the Grand Bank.

The patterns shown in our study are evidence of a distributional shift rather than a change in the timing of the spring inshore migration or changes in vertical distribution of the schools. The weekly movements of schools ran parallel to the shelf edge at all times. There was no evidence of movement towards or away from land. Although it is true that changes in catchability due to vertical distribution shifts would not be detected by the bottom gear used in our study, the lack of fish traces on the sounders of trawlers searching for fish to the north in later years suggests that the fish were absent from the area, rather than higher in the water column away from the gear. North of $48^{\circ} 00^{\prime}$, the three areas most frequented by dense schools during spawning were in relatively deep water on the outer part of the shelf. These areas covered only $16 \%$ of the area fished but contained $70 \%$ of the biomass, and the fish at these locations were maturing or ripe (Wroblewski et al., 1995). However, based on research cruise data gathered since 1946, Hutchings et al. (1993) suggested that on the
Grand Banks, the north-east Newfoundland Shelf, and the Labrador Shelf (the latter two our study area), cod spawn predominantly on the shelf, inshore from the edge. In contrast to Hutchings et al. (1993), our findings agree with earlier studies such as those of Serebryakov (1965, 1968), Fitzpatrick and Miller (1979), and deYoung and Rose (1993) which showed that spawning occurred on the shelf break off Hamilton, Belle Isle, and Funk Island Banks, particularly to the north. Our study deals only with the years after 1980, a much shorter period than the Hutchings et al. (1993) study, and during a time when the winter concentrations of fish seemed to be progressively dispersing into deeper water. In addition, their research cruise data from the area north of $48^{\circ} 00^{\prime} \mathrm{N}$ (where we observed large concentrations of mature cod) was sparse and excluded data taken from depths greater than $500 \mathrm{~m}$. As such, the Hutchings study may not have reflected a change in the spawning activity during the most recent years. Their data from deeper waters may not have been adequate to reflect the extent of the spawning distribution along the edge of the north-east Newfoundland Shelf, and so the spawning distribution that we observed during the 1980s and 1990s may have been quite different from earlier years.

Helbig et al. (1992), using numerical simulations of particle drift, suggested that reproductive activity of cod on the Labrador Shelf is separate from that of the 


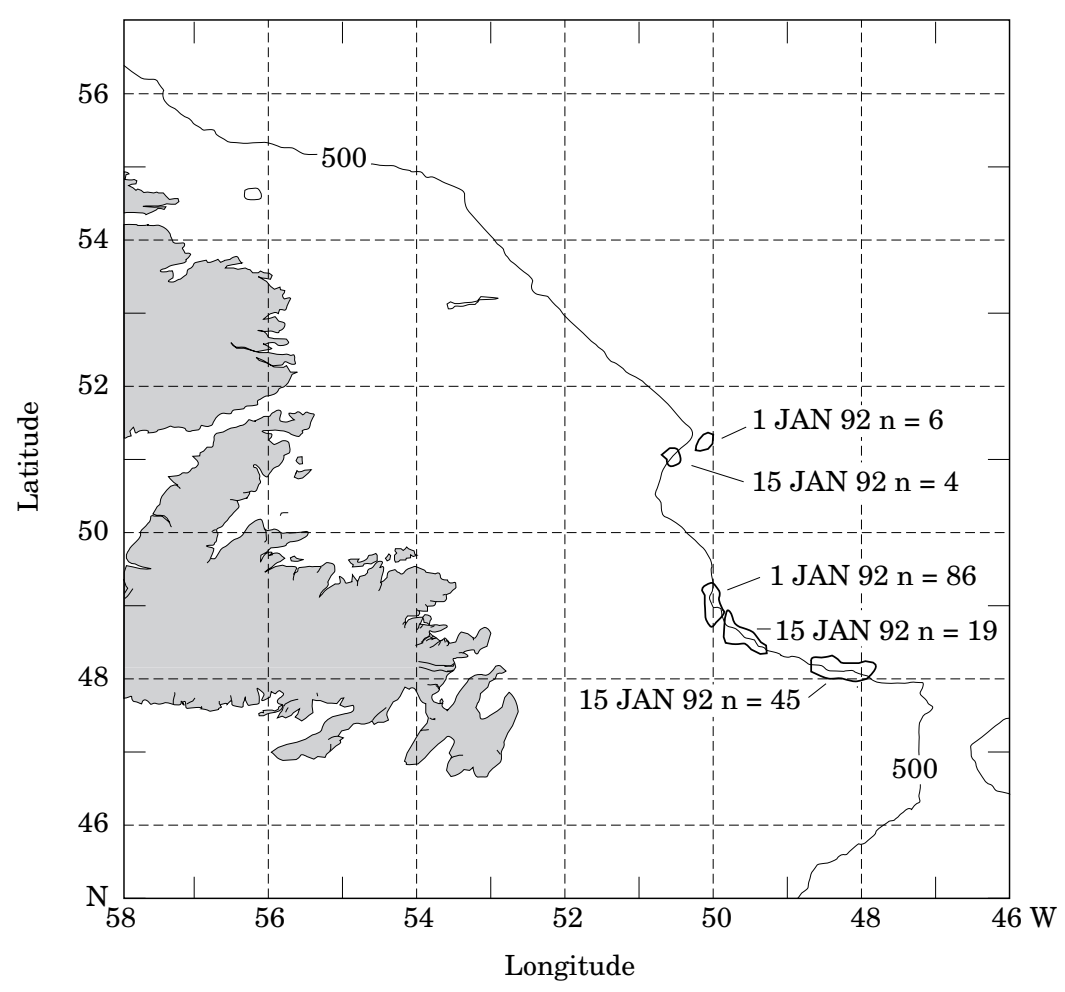

Figure 8. Clusters of tows catching $>5000 \mathrm{~kg} \mathrm{~h}^{-1}$ of cod during January 1992.

Grand Banks. It is entirely possible that the spawning behaviour and distributions of the two areas are quite different, with the Labrador component occurring along the edge. Thus, it may not be appropriate to treat the two as a single, homogeneous entity. We conclude that the distributional and behavioural aspects described in the present paper correspond to the Labrador Shelf spawning concentrations.

Rose et al. (1994) suggested a relationship between water temperature and cod distribution where cod in particular tended to be distributed more to the south in the relatively cold years of 1984-1985 and 1990-1992, and more to the north in the warm years of 1981-1983 and 1986-1988. However, correlation analysis of research survey data with water temperature at Station $27\left(47^{\circ} 32.8^{\prime} \mathrm{N}, 52^{\circ} 35.2^{\prime} \mathrm{W}\right)$ revealed only a weak relationship between population size and water temperature (Narayanan et al., 1993). How the changes in distribution and behaviour of the schools relate to the decline in biomass, and what affected these changes, is not clearly understood, but both the southward shift in distribution and dispersion to greater depths of the spawning schools may have affected survival of the progeny. deYoung and Rose (1993) hypothesized that a southerly shift in the distribution of the spawning cod may have a significant impact on their reproductive success because spawning at southerly locations would lead to reduced larval retention. It may have taken several years of this distributional shift to have a significant effect on population biomass. Helbig et al. (1992) and Hutchings et al. (1993) suggested that deep spawning habits would be detrimental to recruitment since the currents over deeper water would tend to transport the larvae away from the shelf and thus reduce survival. The present study provides further evidence that spawning concentrations during the 1980s and 1990s did change their distribution and behaviour significantly. Schools stayed south and shifted to deeper waters and these changes started several years before the biomass collapse.

Overfishing in conjunction with colder water, some other changing physical influence, altered food supply, increased predator population or a combination of these factors may have contributed to the distributional shift. This in turn may have affected recruitment success or even the health of the adult portion of the stock. While Hutchings and Myers (1994) stressed the importance of overfishing to the decline, Atkinson (1993) and Gomes et al. (1995) showed that not only cod but most groundfish species on the Labrador and north-east Newfoundland shelves declined rapidly after 1989 with an apparent shift southward and to deeper water. In fact, Atkinson (1993) suggested that the proportion of cod to the total biomass of fish actually appeared to increase between 1981 and 1991, indicating a faster 

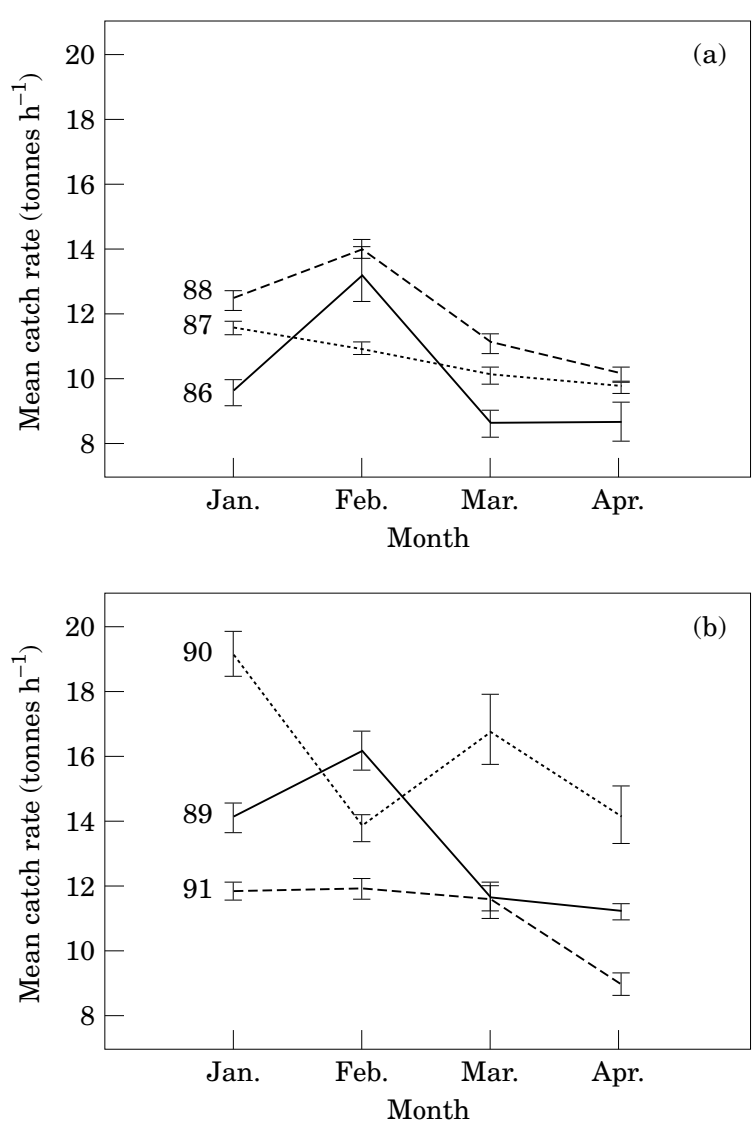

Figure 9. Mean ( \pm standard error) catch rates (tonnes $\mathrm{h}^{-1}$ ) within schools of cod for January-April during the years (a) 1986-1988 and (b) 1989-1991.

decline of other species. While fishing pressure no doubt had a considerable effect on cod biomass, some nontarget species declined at least as quickly. This suggests the importance of an environmental effect in the recent decline of the northern cod stock as well as other species. It is obvious that only when the cause and affect of these ecological relationships are better understood, in conjunction with more accurate and detailed fishing statistics, will we be able to improve our predictive powers when assessing fish resources such as northern cod.

\section{Acknowledgements}

Funding for this research has been provided by the Atlantic Fisheries Adjustment Program's (AFAP) Northern Cod Science Program (D.W.K. and S.N.) and by the Natural Sciences and Engineering Research Council of Canada (NSERC) with National Sea Products Ltd and Fishery Products International Ltd under NSERC's Research Partnerships Program (J.S.W.). We acknowledge the very significant contribution of the fishery observers who collected data aboard commercial trawlers, often under adverse sea conditions. D. Pitcher, and F. Perry assisted with the computing.

\section{References}

Atkinson, D. B. 1993. Some observations on the biomass and abundance of fish captured during stratified random bottom trawl surveys in NAFO Divisions 2J3KL, Fall 1981-1991. NAFO SCR Doc. 93/29, Serial No. N2209, 18 pp.

Baird, J. W., Bishop, C. A., Brodie, W. B., and Murphy E. F. 1992. An assessment of the cod stock in NAFO Divisions 2J3KL. NAFO SCR Doc. 92/18, Serial No. N2063, 69 pp.

Bishop, C. A., Murphy, E. F., Davis, M. B., Baird, J. W., and Rose, G. A. 1993. An assessment of the cod stock in NAFO Divisions 2J+3KL. NAFO SCR Doc. 93/86, Serial No. N2271, 51 pp.

Burrough, P. A. 1986. Principles of Geographical Information Systems for land resource assessment. Clarendon Press, Oxford.

Davis, M. B. 1991. Description of the inshore fishery during 1991 for $2 \mathrm{~J} 3 \mathrm{KL}$ cod as reported by inshore fisherpersons. CAFSAC Res. Doc. 92/37, 6 pp.

deYoung, A., and Rose, G. A. 1993. On recruitment and distribution of Atlantic cod (Gadus morhua) off Newfoundland. Canadian Journal of Fisheries and Aquatic Sciences, 50: 2729-2741.

Fitzpatrick, C., and Miller, R. J. 1979. Review of the spawning times and location for some commercial finfish on the Newfoundland and Labrador coasts. Fisheries Marine Service Technical Report, 905. 14 pp.

Gavaris, S. 1980. Use of a multiplicative model to estimate catch rate and effort from commercial data. Canadian Journal of Fisheries and Aquatic Sciences, 37: 2272-2275.

Gomes, M. C., Haedrich, R. L., Villagarcia, M. G. 1995. Spatial and temporal changes in the groundfish assemblages on the north-east Newfoundland/Labrador Shelf, north-west Atlantic, 1978-1991. Fisheries Oceanography, 4: 85-101.

Gulland, J. A. 1956. On the fishing effort in English demersal fisheries. Fisheries Investigations, London, (2) 20(5), $41 \mathrm{pp}$.

Harris, L. 1990. Independent review of the state of the northern cod stock. Prepared for the Hon. Thomas Siddon, Minister of Fisheries. Communications Directorate, Department of Fisheries and Oceans, Ottawa Ontario. 145 pp.

Helbig, J., Mertz, G., and Pepin, P. 1992. Environmental influences on the recruitment of Newfoundland/Labrador cod. Fisheries Oceanography, 1: 39-56.

Hilborn, R., and Walters, C. 1992. Quantitative fisheries stock assessment. Chapman and Hall, New York, N.Y. $570 \mathrm{pp}$.

Hutchings, J. A., Myers, R. A., and Lilly, G. R. 1993. Geographic variation in the spawning of Atlantic cod, Gadus morhua, in the Northwest Atlantic. Canadian Journal of Fisheries and Aquatic Sciences, 50: 2457-2467.

Hutchings, J. A., and Myers, R. A. 1994. What can be learned from the collapse of a renewable resource? Atlantic cod, Gadus morhua, of Newfoundland and Labrador. Canadian Journal of Fisheries and Aquatic Sciences, 51: 2126-2146.

Kulka, D. W. 1990. Areal patterns in the 2J3KL offshore witch fishery, 1979-1989. CAFSAC Res. Doc. 90/82, 9 pp.

Kulka, D. W., and Firth, J. R. 1987. Observer Program Training Manual-Newfoundland Region. Canadian Technical Report of Fisheries and Aquatic Sciences No 1355 (Revised). 197 pp.

Lear, W. H. 1984. Discrimination of the stock complex of Atlantic cod (Gadus morhua) off southern Labrador and 
eastern Newfoundland, as inferred from tagging studies. Journal of Northwest Atlantic Fisheries Science, 5: 143-159.

Lear, W. H., and Green, J. M. 1984. Migration of the "northern" Atlantic cod and the mechanisms involved In Mechanisms Migration in Fishes, pp. 309-315. Ed. by J. D. McCleave, G. P. Arnold, J. J. Dobson and W. H. Neill. Plenum.

Lear, W. H. MS 1986. The stock complex of Atlantic cod (Gadus morhua) in NAFO Divisions $2 \mathrm{~J}, 3 \mathrm{~K}$ and $3 \mathrm{~L}$. NAFO SCR Doc. 86/32, Serial No. N1146, 13 pp.

Lear, W. H., and Parsons, L. S. 1993. History and management of the fishery for northern cod in NAFO Division $2 \mathrm{~J}, 3 \mathrm{~K}$ and 3L. pp. 55-89. In Perspectives on Canadian marine fisheries management, 226 pp. Ed. by L. S. Parsons and W. H. Lear. Canadian Bulletin of Fisheries and Aquatic Sciences.

Lilly, G. R. 1994. Predation by Atlantic cod on capelin on southern Labrador and Northeast Newfoundland shelves during a period of changing spatial distributions. ICES Marine Science Symposia, 198: 600-611.

Myers, R. A., Mertz, G., and Bishop, C. A. 1993. Cod spawning in relation to physical and biological cycles of the northern north-west Atlantic. Fisheries Oceanography, 2: $154-165$.

Narayanan S., Baird, J. W., Bishop, C. A., and Lilly, G. R. 1993. Climatic Effects on cod distribution deduced from trawl surveys. NAFO SCR Doc. 93/33, Serial No. N2213, 8 pp.
Rose, G. A. 1993. Cod spawning on a migration highway. Nature, 366: 458-461.

Rose, G. A., Atkinson, B. A., Baird, J. W., Bishop, C. A., and Kulka, D. W. 1994. Atlantic cod distribution changes and thermal variations in Newfoundland waters, 1980-1992. ICES Marine Science Symposia, 198: 542-552.

Scheffe, H. 1959. The analysis of variance. John Wiley \& Sons, Inc., New York.

Serebryakov, V. P. 1965. Some results of the Soviet research work on ichthyoplankton in the northwest Atlantic: eggs and larval cod. ICNAF Special Publications, 6: 425-431.

Serebryakov, V. P. 1968. Cod reproduction in the northwest Atlantic. Fisheries Research Board of Canada Translation Ser. No. 1133, 53 pp (Trudy PINRO 1967, 20: 425-242).

Taggart C. T., Anderson, J., Bishop, C., Colbourne, E., Hutchings, J., Lilly, G., Morgan, J., Murphy, E., Myers, R., Rose, G., and Shelton, P. 1994. Overview of cod stocks, biology, and environment in the northwest Atlantic region of Newfoundland with emphasis on northern cod. ICES Marine Science Symposia, 198: 140-157.

Wroblewski, J. S., Kulka, D. W., Narayanan, S., Oake, A., Collier, A., and McGrath, B. 1995. Winter distribution and movements of northern Atlantic cod (Gadus morhua) along the Newfoundland-Labrador continental shelf edge derived from observations on commerical trawlers. Fisheries Oceanography, 4: 128-146. 